IJBPAS, September, Special Issue, 2021, 10(9): 672-681

ISSN: 2277-4998

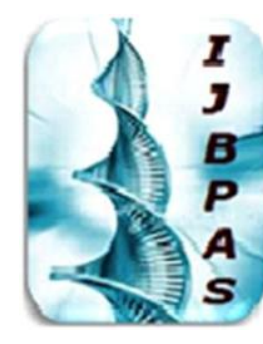

International Journal of Biology, Pharmacy and Allied Seiences (IJBPAS)

'A Bridge Betuen Caboratory and QRenda'

Www.ijbpas.com

\title{
PHYTOCHEMICAL AND IN VITRO ANTI-INFLAMMATORY SCREENING OF INDIGOFERA SPECIES
}

S KARUNAKAR ${ }^{1}$, E SUJATHA ${ }^{1 *}$, S ANURADHA ${ }^{2}$, N VANITHA ${ }^{3}$

1: Department of Botany, Osmania University, Telangana, India, 500007

2: Department of Botany, Government Degree College Chevella, 501503

3: Department of Chemistry, RK Degree College, Kamareddy, 503111

*Corresponding Author: Dr. Sujatha E: E Mail: sujatha@osmania.ac.in

Received 25 ${ }^{\text {th }}$ June 2021; Revised $28^{\text {th }}$ July 2021; Accepted $29^{\text {th }}$ Aug. 2021; Available online $2^{\text {th }}$ Sept. 2021

https://doi.org/10.31032/IJBPAS/2021/10.9.1052

\begin{abstract}
Objective: Current research is to investigated the anti-inflammatory activity of two Indian medicinal plants, Indigofera cordifolia and Indigofera glandulosa.

Methods: Leaves of the both plants were collected and extracted with ethanol. Both ethanolic extracts were subjected to invitro anti-inflammatory activity evaluation by HRBC assay and COX enzyme Inhibition assay. COX-1 inhibition assay employed indomethacin as reference standard, while COX-2 inhibition assay employed celecoxib as reference.

Results: Indigofera cordifolia displayed highest percentage protection of $80.9 \pm 3.3$ in HRBC assay, and percentage inhibition of $72.9 \pm 3.4$ against COX-1, and 80.3 \pm 1.4 against COX-2. Indigofera glandulosa displayed relatively low percentage inhibition of $69.4 \pm 1.4$ against COX1 and $75.8 \pm 2.7$ against COX-2.

Conclusion: Both plants under investigation displayed good anti-inflammatory activity. Comparatively Indigofera cordifolia disclosed more anti-inflammatory activity and specificity towards COX-2 enzyme than Indigofera glandulosa.
\end{abstract}

Keywords: Indigofera cordifolia, Indigofera glandulosa, Extraction, Anti-inflammatory activity 


\section{INTRODUCTION}

Inflammation usually occurs when infectious microorganisms such as bacteria, viruses or fungi invade the body, reside in particular tissues and/or circulate in the blood [1-3]. Inflammation may also happen in response to processes such as tissue injury, cell death, cancer, ischemia and degeneration $[4,5]$. Mostly, both the innate immune response and the adaptive immune response are involved in the formation of inflammation [6]. The innate immune system is the foremost defense mechanism against invading microorganisms and cancer cells, affecting the activity of various cells, including macrophages, mast cells, and dendritic cells. The adaptive immune systems involve the activity of more specialized cells such as B and T cells which are responsible for eradicating invading pathogens and cancer cells by producing specific receptors and antibodies [7-9].

The majority of the therapeutic agents for treating inflammation-related diseases are of synthetic origin called NSAIDs. NSAIDs can reduce inflammation by blocking the metabolism of arachidonic acid by isoform of cyclooxygenase enzyme (COX-1 and/or COX-2), thereby reducing the production of prostaglandin. Numerous NSAIDs developed and marketed all over the globe, are prone to significant side effects viz., Gastric ulcers, Renal damage, internal bleeding risk and hypertension [10]. In the context of safer medicines, the whole research community turned their interest into nature-centric medicines, which were so famous in the Indian subcontinent Ayurveda and Herbal based therapies stand as an alternative to the drugs of synthetic origin with their potency and minimal side effects. Ayurveda and Chinese medicinal systems are the most acceptable traditional systems with the considerable research on pharmacognosy, chemistry, pharmacology, and clinical therapeutics [11, 12].

The Indian subcontinent is richly endowed with diverse medicinal plants with anti-inflammatory activities that are effective in treating inflammatory conditions in traditional medicine. Several research reports proved the antiinflammatory activity of Indian medicinal plant extracts [13-17] and isolated compounds $[18,19]$. The practice of using plants, their parts, or extracts as antiinflammatory compounds has been known since antiquity. The use of plants or plant products for medicinal purposes was mainly documented from Vedic times to the modern era.

The genus Indigofera contains many species, and this abundance can be 
explained by their ability to adapt to different biomes and their intercontinental dispersion [20]. Numerous plants from the Indigofera genus have antioxidant, antimicrobial, anti-inflammatory, anticancer activity, etc. [21-23]. Bearing the potential applications of genus Indigofera, current research focused on evaluating the phytochemical and antiinflammatory activity of two plants, namely Indigofera cordifolia and Indigofera glandulosa.

\section{MATERIALS AND METHODS:}

\section{Reagents and chemicals}

All the chemicals, reagents were reagent grade, procured from Sigma Aldrich (laboratory grade), and the media were purchased from Hi-media.

\section{Plants Material and Preparation of extracts}

Aerial parts of Indigofera cordifolia and Indigofera glandulosa. were collected from the Osmania University campus, Hyderabad. The collected plant materials were shade-dried, powdered, and subjected to Soxhlet extraction with ethanol. The solvent was evaporated under vacuum to dryness to get the solid extract, and percentage yield was calculated.

\section{Phytochemical Analysis}

The preliminary phytochemical investigation of ethanolic extract of Indigofera cordifolia and Indigofera glandulosa were carried out by employing standard protocols. The ethanolic extracts of both plants were tested for the presence of alkaloids, saponins, glycosides, flavonoids, terpenoids, steroids, tannins, etc.

\section{Invitro anti-inflammatory activity HRBC Method}

The human red blood cells (HRBC) method was used to estimate in vitro antiinflammatory activity. The solutions used in this method are: i) Alsever's solution which was prepared dissolving $2.05 \%$ glucose, $0.41 \% \mathrm{NaCl}, \quad 0.81 \%$ trisodium citrate and $0.056 \%$ citric acid, in distilled water to final volume of $100 \mathrm{ml}$; ii) Hyposaline $(0.7 \% \quad \mathrm{NaCl})$; iii) Isosaline (0.9\% NaCl); and iv) Phosphate buffer ( $\mathrm{pH}$ 7.4). Blood $(5 \mathrm{ml})$ was collected from a healthy volunteer and mixed with an equal volume of sterilized Alsever's solution [24]. The serum was obtained by centrifugation at $4000 \mathrm{rpm}$ for $12 \mathrm{~min}$., and the red blood cells (packed cells) were separated. The HRBC suspension was prepared by washing packed cells with isosaline solution $(3 \mathrm{ml} \times 2$ ), then the volume was adjusted to $10 \mathrm{ml}$ with isosaline solution; 50, 100, and $200 \mathrm{mg}$ of celery, myrrh, and fenugreek extracts were used. The dosages were dissolved in $1 \mathrm{ml}$ of distilled water for the aqueous extracts, while the alcoholic fenugreek extract was 
dissolved in $1 \mathrm{ml}$ of $95 \%$ ethanol. Samples of each plant extract, control, and standard (indomethacin, at a dose 50, 75, $100 \mathrm{mg}$ ) were separately mixed with $1 \mathrm{ml}$ of phosphate buffer, $2 \mathrm{ml}$ of hyposaline, and $0.5 \mathrm{ml}$ of HRBC suspension. The assay mixtures were incubated at $36.5^{\circ} \mathrm{C}$ for 30 min. in an oven; they were centrifuged at $3000 \mathrm{rpm}$ for $10 \mathrm{~min}$. The supernatant was decanted, and haemoglobin content was estimated using a spectrophotometer at 560 $\mathrm{nm}$ wavelength. The percentages of haemolysis were estimated by assuming the haemolysis produced in control as $100 \%$, according to the following equation [25].

$\%$ Protection $=100-\frac{(\text { Absorbance of sample })}{(\text { Absorbance of Control })}$

\section{Cyclooxygenase Inhibition Assay}

In vitro COX-1 and COX-2 inhibition potency was estimated by Enzyme Immunoassay (EIA) method. EIA kit was used to examine the plant extracts activity toward COX-1 and COX-2 inhibition. The plant extracts were dissolved in $1 \mathrm{ml}$ of DMSO (99\%) in different amounts $(25,50$, 100, and $200 \mu \mathrm{g} / \mathrm{ml}$ ) to estimate the inhibition activities according to the manufacturer's protocol [26]. Indomethacin and Celecoxib were used as a positive control for COX-1 and COX-2 assays, respectively, in concentrations $25,50,100$, and $200 \mu \mathrm{g} / \mathrm{ml}$. $10 \mu \mathrm{l}$ of plant extracts and positive control concentrations were added to the reagents from EIA kit, $960 \mu 1$ reaction buffer solution, $10 \mu \mathrm{l}$ COX-1, and COX-2 enzymes and $10 \mu \mathrm{l}$ heme. Then the solutions were incubated for $10 \mathrm{~min}$ at $36.5^{\circ} \mathrm{C}$; after that, $10 \mu 1$ of Arachidonic Acid (AA) were added: immediately afterward $50 \mu$ of $1 \mathrm{M}$ $\mathrm{HCl}$ was added to finish the $\mathrm{COX}$ reaction. Stannous chloride $(100 \mu \mathrm{l})$ was added to convert prostaglandin $\mathrm{H} 2 \quad(\mathrm{PG}-\mathrm{H} 2)$ to prostaglandin $\mathrm{F} 2 \alpha(\mathrm{PG}-\mathrm{F} 2 \alpha)$ via reduction reaction, the COX enzyme-catalyzed reaction of arachidonic acid to produce PG$\mathrm{H} 2$ [27]. When the color of the solution became yellow, the concentration of the PGF2 $\alpha$ was estimated spectro- photometrically using a UV-Vis spectrophotometer at 418 $\mathrm{nm}$. The percent of inhibition was calculated by comparing extracts measurements with control assessment [28, 29].

\section{RESULTS AND DISCUSSION}

\section{Preliminary phytochemical screening}

The preliminary phytochemical study of ethanolic extracts of Indigofera cordifolia and Indigofera glandulosa. exposed that the extracts are instituted with various secondary metabolites such as alkaloids, carbohydrates, flavonoids, phenols, steroids, terpenoids, glycosides, tannins, saponins (Table 1).

\section{Invitro anti-inflammatory activity HRBC Method}

Results of human red blood cell membrane protection percentage of ethanolic extract 
of Indigofera cordifolia and Indigofera glandulosa were given in Table 2 and Figure 1. The percentage protection of ethanolic extracts of Indigofera cordifolia and Indigofera glandulosa at $200 \mu \mathrm{g} / \mathrm{ml}$ was $80.9 \pm 3.3$ and $71.6 \pm 1.4$ respectively compared to the standard drug indomethacin which exhibited percentage protection of $94.3 \pm 2.8$ at $200 \mu \mathrm{g} / \mathrm{ml}$.

From the results of HRBC method, it is apparent that both Indigofera cordifolia and Indigofera glandulosa displayed noticeable anti-inflammatory potential relative to the standard drug indomethacin. It is important to note that at $100 \mu \mathrm{g} / \mathrm{ml}$ and $200 \mu \mathrm{g} / \mathrm{ml}$ concentrations, the extracts displayed good anti-inflammatory potential than the lower concentrations $25 \mu \mathrm{g} / \mathrm{ml}$ and $50 \mu \mathrm{g} / \mathrm{ml}$. A dose-dependent trend is observed in the anti-inflammatory activity in both plant extracts. In between the two extracts, Indigofera cordifolia ethanolic extract relatively displayed more potency than Indigofera glandulosa.

\section{Cyclooxygenase Inhibition Activity}

COX-1 and COX-2 enzyme inhibition assay results were displayed in Table $\mathbf{3}$, Figures 2 and 3. Both COX-1 and COX-2 enzymes were actively inhibited. In the case of COX-1 enzyme, both ethanolic extracts displayed relatively significant $(\mathrm{p}<0.05)$ activity at the dose of $200 \mu \mathrm{g} / \mathrm{ml}$ with percentage inhibition of $72.9 \pm 3.4$ (Indigofera cordifolia), $\quad 69.4 \pm 1.4$ (Indigofera glandulosa) compared to the standard indomethacin $\quad(95.4 \pm 3.1)$. Similarly, at the concentration of $200 \mu \mathrm{g} / \mathrm{ml}$, both ethanolic extracts displayed significant $(\mathrm{p}<0.05)$ inhibitory activity against COX -2 with percentage inhibition of $80.3 \pm 1.4$ (Indigofera cordifolia)75.8 \pm 2.7 (Indigofera glandulosa) compared to the standard drug Celecoxib (96.02 \pm 2.4$)$.

From the invitro COX inhibitory assay results, it is evident that both Indigofera cordifolia and Indigofera glandulosa plant ethanolic extracts are active against COX-1 and COX-2 enzymes. It was observed that Indigofera cordifolia ethanolic extract is a more active against the cyclooxygenase enzyme than Indigofera glandulosa. Percentage inhibition values of both extracts also implies that Indigofera cordifolia is relatively displayed more specificity towards COX -2 than COX-1 enzyme.

Table 1: Phytochemical screening of Indigofera cordifolia and Indigofera glandulosa.

\begin{tabular}{|c|c|c|}
\hline Phytochemicals & $\begin{array}{c}\text { Ethanol extract of Indigofera } \\
\text { cordifolia }\end{array}$ & $\begin{array}{c}\text { Ethanol extract of Indigofera } \\
\text { glandulosa }\end{array}$ \\
\hline Alkaloids & + & + \\
\hline Glycosides & + & + \\
\hline Flavonoids & + & + \\
\hline Terpenoids & + & + \\
\hline Steroids & + & + \\
\hline Tannins & + & + \\
\hline Proteins & + & + \\
\hline
\end{tabular}




\begin{tabular}{|c|c|c|}
\hline Carbohydrates & + & + \\
\hline Amino acids & + & + \\
\hline Saponins & + & + \\
\hline
\end{tabular}

Table 2: Results of HRBC Method

\begin{tabular}{|c|c|c|}
\hline Sample & Concentration $(\mu \mathrm{g} / \mathrm{ml})$ & Percentage protection \\
\hline \multirow{4}{*}{ Indigofera cordifolia } & 25 & $20.7 \pm 1.9$ \\
\cline { 2 - 3 } & 50 & $47.9 \pm 1.8$ \\
\cline { 2 - 3 } & 100 & $70.8 \pm 3.7^{*}$ \\
\cline { 2 - 3 } Indigofera glandulosa & 200 & $\mathbf{8 0 . 9} \pm 3.3^{*}$ \\
\cline { 2 - 3 } & 25 & $20.7 \pm 1.9$ \\
\cline { 2 - 3 } & 50 & $36.8 \pm 4.5$ \\
\cline { 2 - 3 } & 100 & $\mathbf{5 4 . 9} \pm 2.7$ \\
\hline \multirow{3}{*}{ Indomethacin } & 200 & $\mathbf{7 1 . 6} \pm 1.4^{*}$ \\
\cline { 2 - 3 } & 25 & $\mathbf{2 3 . 8} \pm 4.7$ \\
\cline { 2 - 3 } & $\mathbf{5 0}$ & $\mathbf{8 6 . 0 4} \pm 3.9$ \\
\cline { 2 - 3 } & 100 & $\mathbf{9 4 . 3} \pm 2.8^{*}$ \\
\hline
\end{tabular}

\section{HRBC Assay}

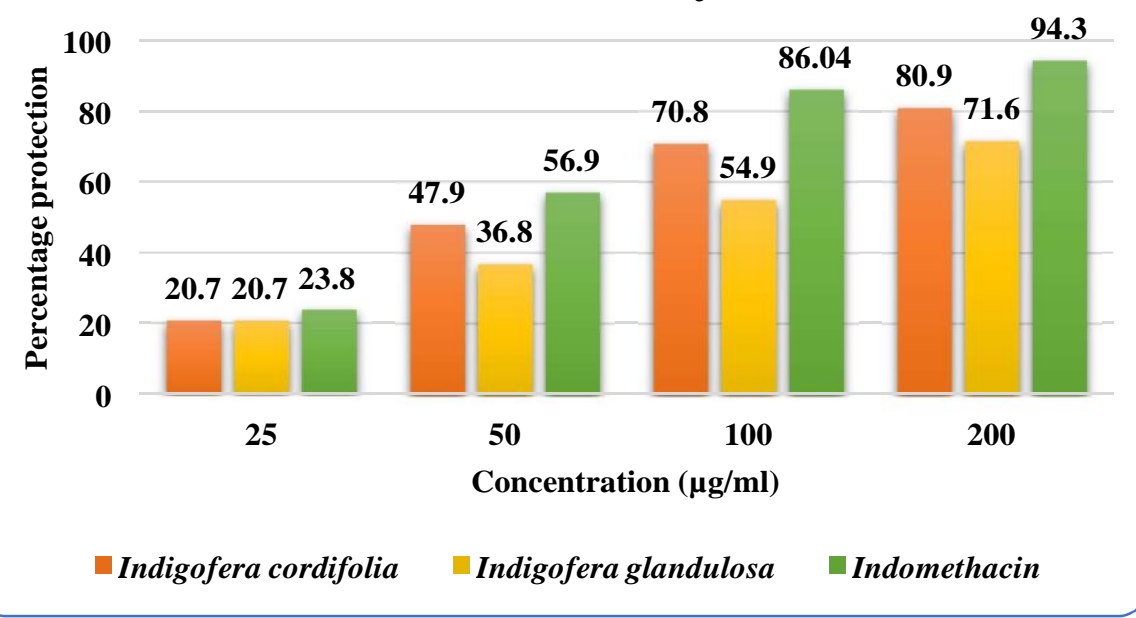

Figure 1: Graphical Representation of HRBC assay (\% protection) of Ethanolic extract of Indigofera cordifolia and Indigofera glandulosa

Table 3: Results of COX enzyme inhibition assay

\begin{tabular}{|c|c|c|c|}
\hline Sample & $\begin{array}{c}\text { Concentration } \\
(\mu \mathrm{g} / \mathrm{ml})\end{array}$ & $\begin{array}{c}\text { COX-1 } \\
\text { (\% } \text { Inhibition) }\end{array}$ & $\begin{array}{c}\text { COX-2 } \\
\text { (\% Inhibition) }\end{array}$ \\
\hline \multirow{4}{*}{ Indigofera cordifolia } & 25 & $23.8 \pm 3.4$ & $29.4 \pm 1.9$ \\
\hline & $\mathbf{5 0}$ & $39.3 \pm 2.7$ & $43.2 \pm 3.9$ \\
\hline & 100 & $60.8 \pm 1.6^{*}$ & $63.7 \pm 2.7$ \\
\hline & 200 & $72.9 \pm 3.4 *$ & $80.3 \pm 1.4 *$ \\
\hline \multirow{4}{*}{ Indigofera glandulosa } & 25 & $20.8 \pm 2.8$ & $21.9 \pm 2.4$ \\
\hline & 50 & $35.8 \pm 2.2$ & $38.2 \pm 4.8$ \\
\hline & 100 & $58.1 \pm 3.1$ & $60.09 \pm 4.1$ \\
\hline & 200 & $69.4 \pm 1.4 *$ & $75.8 \pm 2.7 *$ \\
\hline \multirow{4}{*}{ Indomethacin } & 25 & $34.4 \pm 1.8$ & $32.6 \pm 1.4$ \\
\hline & 50 & $63.7 \pm 3.2$ & $66.8 \pm 3.3$ \\
\hline & 100 & $89.9 \pm 2.8 *$ & $91.7 \pm 1.6 *$ \\
\hline & 200 & $95.4 \pm 3.1 *$ & $96.02 \pm 2.4^{*}$ \\
\hline
\end{tabular}




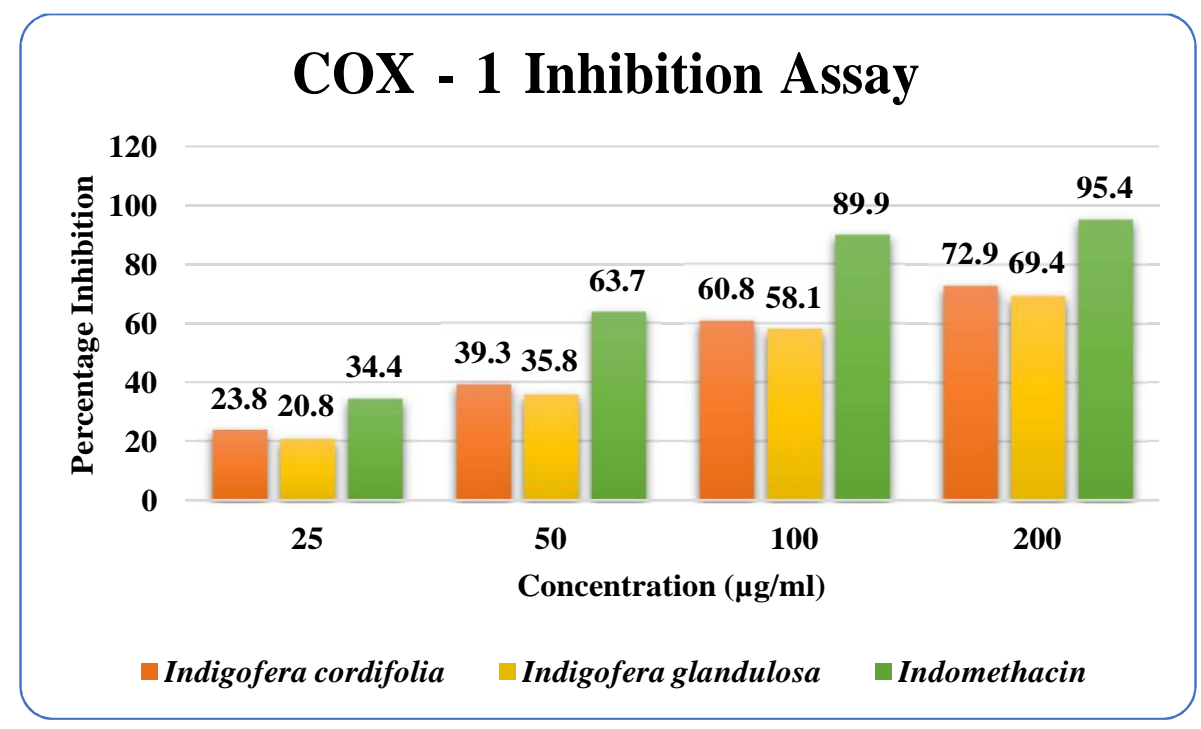

Figure 2: Graphical Representation of COX-1 Inhibition assay of Ethanolic extract of Indigofera cordifolia and Indigofera glandulosa

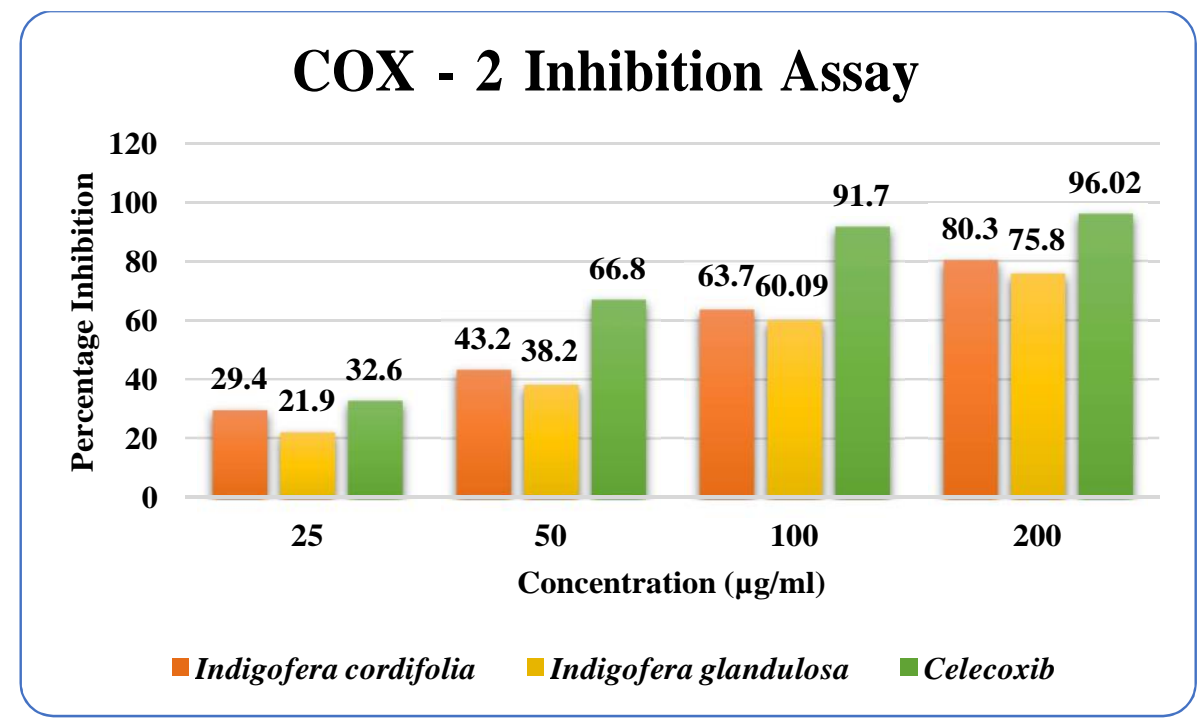

Figure 3: Graphical Representation of COX-2 Inhibition assay of Ethanolic extract of Indigofera cordifolia and Indigofera glandulosa

\section{CONCLUSION}

Two medicinal plants, Indigofera cordifolia and Indigofera glandulosa were extracted with ethanol. The phytochemical analysis affirm the presence of major secondary metabolites such as alkaloids and flavonoids terpenoids, steroids, glycosides and tannins. Anti-inflammatory activity evaluation by HRBC assay and COX enzyme inhibition assay revealed the antiinflammatory potential of the ethanolic extracts of Indigofera cordifolia and Indigofera glandulosa. Indigofera cordifolia ethanolic extract proved to be more active against COX-1 and COX-2 than Indigofera glandulosa. 


\section{Acknowledgement}

The authors are thankful to the Department of Botany, Osmania University, Hyderabad, for providing the necessary facilities to complete current research successfully.

\section{Conflict of Interest}

None

\section{REFERENCES}

[1] Artis, D.; Spits, H. The biology of innate lymphoid cells. Nature 2015, 517, 293-301.

[2] Isailovic, N.; Daigo, K.; Mantovani, A.; Selmi, C. Interleukin-17 and innate immunity in infections and chronic inflammation. J. Autoimmun. 2015, 60, 1-11.

[3] Pedraza-Alva, G.; Pérez-Martínez, L.; Valdez-Hernández, L.; MezaSosa, K.F.; Ando-Kuri, M. Negative regulation of the inflammasome: Keeping inflammation under control. Immunol. Rev. 2015, 265, 231-257.

[4] Lucas, S.M.; Rothwell, N.J.; Gibson, R.M. The role of inflammation in CNS injury and disease. Br. J. Pharmacol. 2006, 147, S232-S240.

[5] Rock, K.L.; Lai, J.J.; Kono, H. Innate and adaptive immune responses to cell death. Immunol. Rev. 2011, 243, 191-205.
[6] Fernandes, J.V.; Cobucci, R.N.; Jatobá, C.A.; Fernandes, T.A.; de Azevedo, J.W.; de Araújo, J.M. The role of the mediators of inflammation in cancer development. Pathol. Oncol. Res. 2015, 21, 527-534.

[7] Heppner, F.L.; Ransohoff, R.M.; Becher, B. Immune attack: The role of inflammation in Alzheimer disease. Nat. Rev. Neurosci. 2015, $16,358-372$.

[8] Loane, D.J.; Kumar, A. Microglia in the TBI brain: The good, the bad, and the dysregulated. Exp. Neurol. 2016, 275, 316-327.

[9] Waisman, A.; Liblau, R.S.; Becher, B. Innate and adaptive immune responses in the CNS. Lancet Neurol. 2015, 14, 945-955.

[10] Harirforoosh, S., Asghar, W., \& Jamali, F. (2013). Adverse effects of nonsteroidal antiinflammatory drugs: an update of gastrointestinal, cardiovascular and renal complications. Journal of pharmacy \& pharmaceutical sciences: a publication of the Canadian Society for Pharmaceutical Sciences, Societe canadienne des sciences pharmaceutiques, 16(5), 821-847.

[11] Kiranjot S., Kunwarjeet P. Indigenous use of medicinal plants 
for health care. Ethno Med. 2010;

$4: 145-148$.

[12] Ayannar M., Ignacimuthu S. Ethnobotanical survey of medicinal plants commonly used by the Kani tribals in Tirunelveli hills of Western Ghats, India. J Ethnopharmacol. 2011; 134:851-864.

[13] Chan, K.; Islam, M.W.; Kamil, M.; Radhakrishnan, R.; Zakaria, M.N.M.; Habibullah, M.; Attas, A. The analgesic and antiinflammatory effects of Portulaca oleracea L. subsp. Sativa (Haw.) Celak. J. Ethnopharmacol. 2000, $73,445-451$.

[14] Rahman, M.; Chowdhury, J.A.; Habib, R.; Saha, B.K.; Salauddin, A.D. Islam, M.K. Anti-inflammatory, anti-arthritic and analgesic activity of the alcoholic extract of the plant Urginea indica Kunth. Int. J. Pharm. Sci. Res. 2011, 2, 29152919.

[15] Yasmeen, N.; Sujatha, K. Evaluation of anti-inflammatory activity of ethanolic whole plant extract of Desmodium gangeticum L. Int. J. Phytomed. 2013, 5, 347349.

[16] Saravana, K.K.; Nagaveni, P.; Anitha, K.; Mahaboob, S.T.M. Evaluation of anti-inflammatory activity on Vitex negundo Linn. J. Drug Deliv. Ther. 2013, 3, 41-44.

[17] Gupta, A.; Chaphalkar, S.R. Terpenoids from three medicinal plants and their potential antiinflammatory and immunosuppressive activity on human whole blood and peripheral blood mononuclear cells. Asian J. Ethnopharmacol. Med. Foods 2016, 2, 13-17.

[18] Medicherla, K.; Ketkar, A.; Sahu, B.D.; Sudhakar, G.; Sistla, R. Rosmarinus officinalis L. extract ameliorates intestinal inflammation through MAPKs/NF- $\kappa \mathrm{B}$ signaling in a murine model of acute experimental colitis. Food Funct. 2016, 7, 32333243.

[19] Kumar, R.; Gupta, Y.K.; Singh, S.; Arunraja, S. Picrorhiza kurroa inhibits experimental arthritis through inhibition of proinflammatory cytokines, angiogenesis and MMPs. Phytother. Res. 2016, 30, 112-119.

[20] Schrire, B.D., Lavin, M., Barker, N.P., Forest, F., 2009. Phylogeny of the tribe Indigofereae (Leguminosae-Papilionoideae): geographically structured more in succulent-rich and temperate settings than in grass-rich 
environments. Am. J. Bot. 96,816852.

https://doi.org/10.3732/ajb.0800185.

[21] Dey, A., Gorai, P., Mukherjee, A., Dhan, R., Modak, B.K., 2017. Ethnobiological treatments of neurological conditions in the Chota Nagpur plateau, India. J. Ethnopharmacol. 198, 33-44.

[22] Dkhil, M.A., Moneim, A.E.A., AlQuraishy, S., 2016. Indigofera oblongifolia ameliorates lead acetate-induced testicular oxidative damage and apoptosis in a rat model. Biol. Trace Elem. Res. 173, 354361.

[23] Gerometta, E., Grondin, I., Smadja, J., Frederich, M., \& Gauvin-Bialecki， A. (2020). A review of traditional uses, phytochemistry and pharmacology of the genus Indigofera. Journal of Ethnopharmacology, 112608.

[24] Sumathi P, Parvathi A. Antimicrobial activity of some traditional medicinal plants. JMPR 2010; 4:316-21.

[25] Shenoy S, Shwetha K, Prabhu K, et al. Evaluation of antiinflammatory activity of Tephrosia purpurea in rats. Asian Pac J Trop Med 2010; 3:193-5.

[26] Begum N, Keshetti S, Vattikuti UM. Evaluation of in vitro anti- inflammatory and COX-2 inhibitory activity of leaves of Origanum vulgare. The Pharma Innovation Journal 2016; 5:18-21.

[27] Bisht R, Bhattacharya S, Jaliwala YA. COX and LOX inhibitory potential of Abroma augusta and Desmodium gangeticum. J Phytopharmacol 2014; 3:168-75.

[28] Begum N, Keshetti S, Vattikuti UM. In vitro investigation of antiinflammatory and COX-2 inhibitory potential of flower extracts of Matricaria recutita. IJGP 2017; 11:80-3.

[29] Mohamed-Saleem TK, Azeem AK, Dilip C, et al. Antiinflammatory activity of the leaf extracts of Gendarussa vulgaris Nees. Asian Pac J Trop Biomed 2011; 1:147-9. 